\title{
Are body image and eating attitudes, behaviours, and knowledge of parents of pre-schoolers associated with parent feeding practices?
}

\author{
Stephanie R Damiano ${ }^{*}$, Laura Hart, Susan J Paxton, Chelsea Cornell, Fiona Sutherland \\ From 2014 ANZAED Conference: Driven Bodies Driven Brains \\ Fremantle, Australia. 22-23 August 2014
}

Some parent feeding practices have been linked to disordered eating and higher BMIs in children. Relatively little research has examined factors that influence parent feeding practices. The aim of this study was to identify relationships between the parent feeding practices that have been linked to unhealthy eating patterns in children, and parent body image, eating attitudes, behaviours, and knowledge. Participants were 326 parents of pre-school children from Victoria (97.5\% mothers). Parents completed measures of parent body dissatisfaction, body image knowledge, dieting behaviours, and parent feeding practices of their child closest to four years old (58\% girls, aged 2-6 years). Knowledge scores were inversely associated with a number of negative feeding practices, including instrumental feeding, and with the frequency of parents reporting negative behavioural intentions to brief vignettes reflecting appearance-based stigma. Parent weight and shape concerns were positively associated with restrictive feeding practices, including restricting high-fat foods in their pre-schooler. Parent dieting was positively related to restricting and controlling feeding practices. Given that such parent feeding practices are associated with longterm risk of weight gain and disordered eating in children, these findings highlight the need for prevention interventions for parents of pre-schoolers.

This abstract was presented in the Parental Roles in Prevention and Support stream of the 2014 ANZAED Conference.

Published: 24 November 2014

* Correspondence: s.damiano@latrobe.edu.au

School of Psychological Science, La Trobe University, Melbourne, Australia
doi:10.1186/2050-2974-2-S1-034

Cite this article as: Damiano et al:: Are body image and eating attitudes, behaviours, and knowledge of parents of pre-schoolers associated with parent feeding practices? Journal of Eating Disorders 2014 2(Suppl 1):O34.
Submit your next manuscript to BioMed Central and take full advantage of:

- Convenient online submission

- Thorough peer review

- No space constraints or color figure charges

- Immediate publication on acceptance

- Inclusion in PubMed, CAS, Scopus and Google Scholar

- Research which is freely available for redistribution
() Biomed Central 